\title{
Community Life of Slovaks in Budapest between 1850 and 1875 Ĺuboš KAČíREK
}

\begin{abstract}
This work seeks to provide a picture of the Slovak community in the capital of the Kingdom of Hungary from the period between the conclusion of the 1848/1849 revolution and the onset of the social and political upheavals it brought to the suppression of Slovak national ambitions and all related activities in 1875. They culminated in the closing of Slovak secondary schools and Matica slovenská, as well as the collapse of the New School of the Slovak national movement which attempted reconciliation and cooperation with the Hungarian government.
\end{abstract}

\section{Keywords}

$19^{\text {th }}$ century, Slovak Community, social movement organization, Budapest

\section{Introduction}

The city we know as Budapest - formerly the capital of the Kingdom of Hungary and now the capital of Hungary - officially came into being in 1873 as an amalgamation of the cities of Buda, Óbuda and Pest. In Slovak, the three cities were known before the union as either Pešt'budín or Pešt'-Budín (where Budín is the Slovak name for Buda), although the current term Budapešt' can be found in the Slovak press before 1873. In the Slovak public's eye, Peštbudín was always a foreign city unfriendly to Slovaks and this seemed to be doubly true in the years 1874-1875.

Much of our current knowledge of the daily life of the Slovak community in Peštbudín in the period between the late 1850s and early 1870s is based on two memoires published in the early 1920s in the magazine Slovenské pohlady which established a 'canon' view of Peštbudín in this period. ${ }^{1}$ It must, however, be kept in mind that these memoires came out over fifty years after the event and their description of contemporary personages tends to be skewed by their future actions in favor of - or in opposition to - the national movement

1 BELLA, Ján Pravdol'ub: Niektoré rozpomienky z rokov 1858-64, in: Slovenské pohlady, 38, 1922, 9, 520-523; KLEIN, Belo: Pred polstoletím. Rozpomienky na slovenskú koloniu v Peštbudíne 1873, 1874, in: Slovenské pohlady, 39, 1923, 4 and 5, 220-231; 286-306. 
(e. g. Ján N. Bobula or the brothers Peter and Vojtech Matuška) and this biased view was then often uncritically adopted by subsequent authors.

Consequently, one must rely on other sources when reevaluating the history of the Slovak community in Budapest in this period. Slovak periodicals, which often published essential information on the goings-on in the Peštbudín Slovak community, are the fundamental and the most important such source and these include Pešt'budínske vedomosti, Slovenské noviny a Národnie noviny. Additionally, a number of periodicals regularly provided news from the religious communities (Katolícke noviny, Cyrill a Method and Církevní listy), and detailed information on the life of the Slovak population of Budapest can also be gleamed from literary periodicals published in the capital, such as Junoš and Dunaj. And finally, period correspondence of community leaders and the records of the Slovak Lutheran assembly in Pest remain an invaluable source of information on the life of the Slovak community in Budapest.

Much attention has been devoted to Budapest as one of the centers of the Slovak public life, especially by historians, literary scholars and ethnologists. In the 1950s, Slovak historiography mostly focused on the working class, as Pavol Hapák did in his survey of Slovak laborers in late $19^{\text {th }}$ century in Budapest. ${ }^{2}$ The definitive scholarly history of the famous Liptauer masons, who first began to come to Pešt'budín in late $18^{\text {th }}$ century to work on seasonal construction projects, was written by Miroslav A. Huska ${ }^{3}$. Although the public may be more familiar with the fictional account of Slovak and specially Liptauer migrant masons in the 1979 epic novel Tisícročná včela (The Millennial Bee) by Peter Jaroš. ${ }^{4}$ Most recently, the exhibition Liptovskí murári pomáhali stavat'Budapešt' (Liptauer masons helped build Budapest; 2012) at the SNM-Ethnographic museum in Martin sought to increase the public's awareness of this fascinating part of Slovak history.

Despite the interest, Slovak historiography devoted very little attention to the actual life of the Slovak community in Budapest. The focus seems to be on a small number of personalities who lived in Budapest, such as Ján Kollár, Martin Hamuljak or Ján Palárik, or on a number of cultural societies, like the Slovak Readers' Society or the Slovak Language and Literature Society, the editorial boards of Pešt'budínske vedomosti and the Budapest tenure of Milan Hodža and other members of the Hlas and the Prúdy movements.

First comprehensive works on the Slovak community in Budapest appeared in the late 1920s when the Research Institute of the National Self-Government of Slovaks in Hungary and the Slovak self-govenrment in Budapest published a number of groundbreaking volumes. The first one is a collection of proceedings from a 1997 conference titled Kultúrne dedičstvo budapeštianskych Slovákov (The Cultural Heritage of Budapest Slovaks). ${ }^{5}$ This volume includes papers by Anna Kováčová and Ivan Halász who would later publish extensively on the Slovak community in Budapest and its organized social life. Anna Kováčová did so especially in her monographs which surveyed the civic organizations founded and

2 HAPÁK, Pavol: Slovenské robotnícke hnutie v Budapešti koncom XIX. storočia, in: Historický časopis, 3, 1955,

1, 52-86.

3 HUSKA, Miroslav: Liptovskí murári, Liptovský Mikuláš 1968.

4 JAROŠ, Peter: Tisícročná včela, Bratislava 1979.

5 HRIVNÁK, Michal (ed.): Kultúrne dedičstvo budapeštianskych Slovákov, Budapest 1998. 
ran by Slovaks in late $19^{\text {th }}$ and early $20^{\text {th }}$ century. ${ }^{6}$ Her 2012 collaboration with L. Matus ${ }^{7}$ provided the definitive history of the Slovak Lutheran community in Pest by, among other things, publishing the records of the assembly from its founding to 1974 for the first time. Kováčová combined the fruit of over twenty years of research on the Slovak community in Budapest in her most recent work ${ }^{8}$. Ivan Halász has written extensively on a number of Slovak personages who, at one point or another, made a home in Budapest like Ján Palárik, Ján Bobula and Daniel Bachát. ${ }^{9}$

\section{The Religious and Social Structure of Slovaks in Budapest}

Throughout the entire period between the formation of modern nation states and the dissolution of the Kingdom of Hungary after the conclusion of The Great War, the capital of Hungary was an important cultural and political center for the Slovaks, although its role and importance varied. Today's Budapest, which was formed in 1873, became the capital of the Kingdom of Hungary in 1784 when Emperor Joseph II transferred the central administration of the Kingdom from Pressburg (today's Bratislava) back to Buda. This move was foreshadowed by the Emperor's mother Maria Theresa who in 1777 transferred the Trnava University to Buda (and then in 1785 it was moved to Pest). By the $17^{\text {th }}$ century, the two cities - Buda, the historical capital of the Kingdom and Pest, its counterpart across the river - had fused into a single urban area only separated by the Danube which quickly became a new economic and industrial center of the country, a status only underscored by the transfer of the university and the Hungarian Diet. When the first permanent bridge over Danube opened in 1849, a new metropolis was born which soon incorporated Óbuda, an important industrial center renowned for its shipyards.

The population of Budapest (the city itself as well as its outskirts) gradually grew thanks to natural processes, migration and incorporation of further villages to the new city. In the span of a hundred years, the total population grew more than ten-fold from 60,250 in 1810 to 880,371 in 1910 (1831: 102,702, 1851: 143,289, 1869: 280,349, 1880: 370,767 a 1900 : $733,358) \cdot{ }^{10}$

There is no data available on what share of those people were of Slovak extraction and so all we have to go by are estimates by contemporary figures and official statistics which are,

6 KOVÁČOVÁ, Anna: Život a kultúra Slovákov v Budapešti v období dualizmu (1867-1918), Pilíšska Čaba - Ostrihom 2006; KOVÁČOVÁ, Anna: Po stopách slovenskej minulosti Budapešti. Výber zo štúdií a prednášok, Budapest 2014.

7 KOVÁCS, Anna - MATUS, László: Jób megpróbáltatásai - egy evangélikus gyülekezet sorsfordulói. A pesti szlovák evangélikus gyülekezet emlékkönyve. Utrpenie Jóba - peripetie jedného evanjelického zboru. Pamätnica peštianskeho slovenského evanjelického zboru, Budapest 2012.

8 KOVÁČOVÁ, Po stopách slovenskej ...

9 HALÁSZ, Ivan: Možnosti kariéry pre Slovákov počas dualizmu, in: Kultúrne dedičstvo budapeštianskych Slovákov..., 70-82; HALÁSZ, Ivan: Ján Nepomuk Bobula, in: Szlovák életpályák a dualizmuskori Budapesten. Slovenské životné dráhy v Budapešti v období dualizmu, 57-67; HALÁSZ, Ivan: Cirkev, národ, štát. Daniel Bachát a jeho budapeštianske roky, Esztergom - Piliscsaba 2003; HALÁSZ, Ivan: Vel'komesto a vel'komestské motívy v slovenskej literatúre 19. storočia. "Budapeštianski" autori slovenskej literatúry: Ján Palárik a Daniel Bachát, in: Identita, história a kultúra. Dejiny Slovákov na Dolnej zemi. (Zborník konferencie 11. - 12. novembra 2010), KOVÁČOVÁ, Anna (ed.), Budapest - Békešská Čaba 2011, 72-87.

10 Budapest statistics, Budapest 1945, 29. 
however, inaccurate. Most Slovak newcomers would settle in Pest suburbs of Theresa Town (Terézváros, Theresienstadt) and Joseph Town (Józsefváros, Josephstadt), as in Ján Palárik's opinion, by 1850 s over half of the inhabitants of Theresa Town were Slovak. This tendency, specifically in Joseph Town, is proved also by Katolicke noviny from the beginning of the 50s: "All the streets and colonies there are purely Slovak now."11 As a community, Budapest Slovaks were a very heterogeneous group comprised of people of Slovak extraction from Slovak provinces in Upper Hungary, Slovak ethnic enclaves around Budapest and even from the Slovak Lower Lands.

Even in this new location, the division of the Slovak society along confessional lines (Catholics vs. Lutherans) continued to play an important role in the life of the Slovak community, especially when it comes to the choice of conducting services in their native language or rather lack thereof. This then had direct repercussions not only for language and culture retention, but also for the community's participation in the national cause. Slovak Lutherans in Pest were relatively well organized: the Pest Slovak Lutheran assembly, organized under the Superintendence, was founded by Ján Kollár in 1824. ${ }^{12}$ When he left for Vienna in 1850, the assembly elected Jozef Podhradský (1823-1915), Kollár's former chaplain, as the priest. In 1862, under pressure from those who disagreed with his actions during the 1859 Protestant Patent ${ }^{13}$ crisis, Podhradský resigned from his post. The conflict between the factions abated only in 1867 when Michal Elefant (1816-1872) - who would in $1868 \mathrm{go}$ on to become the senior for Pest - was elected priest. After Elefant's death in 1872, the assembly elected Daniel Bachát ${ }^{14}$ during whose tenure the parish became an important focal point for the Slovak community in Budapest. The Slovak Lutheran assembly not only built its own church, but it also ran its own school. Both were located in the Kerepes (today's Rákóczi) Avenue, where in the 1890s, the community added rental housing ('the bazar') which turned this small part of the city into a full-fledged Slovak Lutheran enclave known to the contemporaries as the Luther Yard. ${ }^{15}$

The situation of Slovak Catholics was a little more complicated. Considering the universal nature of Catholic Church before then Second Vatican Council, no new parishes based on purely ethnic criteria could be created. The only accommodation provided to the Slovak faithful was the attempt of the Church leadership to enable parishioners to hear mass in their native language, but even this was done away with in the late $19^{\text {th }}$ century in favor of Hungarian. Thanks to a dispensation by the Esztergom bishop Alexander Rudnay (18191831), Slovak Catholics in Pest were able to hear mass in Slovak at the Joseph Town Church of St. Joseph and at the Franciscan church in the inner city. ${ }^{16}$ In the late 1850s, there were

11 Z Pešt'-Budína dňa 1-ho julia., in: Katolícke noviny, 1852, year 4, No. 27, 3 July, 6-7.

12 More info: BRTÁŇOVÁ, Erika - HUČKOVÁ, Dana - VANEKOVÁ, Ol'ga - MEZEIOVÁ, Adelaida: Listy Jána Kollára, in: XV. medzinárodný zjazd slavistov v Minsku. Príspevky slovenských slavistov, Bratislava 2013, 195-222; KISS SZEMÁN, Róbert: Slovanský Goethe v Pešti. Ján Kollár a národní emblematismus středoevropských Slovanů, Prague 2014.

13 More: VIRŠINSKÁ, Miriam: Evanjelická cirkev a. v. v Uhorsku a Slováci v druhej polovici 19. storočia, Martin 2011, 90-106; 117-154.

14 HALÁSZ, Cirkev, národ, štát...

15 ZÁSZKALICZKY, Péter (ed.) Oltalom a zivatarban. Gyülekezet a világvárossá fejlődő Budapesten, Budapest 2011; KOVÁCS, Anna - MATUS, László: Jób megpróbáltatásai ...

16 PALÁRIK, Ján: Odpověd' na "Ozvěnu z Peště", in: Cyrill a Method, 1858, Year 9, No. 29, 17 July, 231. 
only approximately 8,000 Slovaks living in Joseph Town while in the St. Theresa parish in Theresa Town where the Slovak community was much larger, the canonical visitation did not allow for a mass in Slovak. The population of Theresa Town increased from 30,000 in the 1820 s to over 50,000 in the late 1850 s, ${ }^{17}$ of which more than 30,000 were Catholic among whom Šimon Klempa and later Ján Palárik ${ }^{18}$ did a large portion of their work.

In addition to the confessional aspect, the social origin of Slovak newcomers played an important role in the way they integrated into the urban society. In numerical terms, the largest groups of Slovaks in the capital were laborers, apprentice craftsmen, apprentice tradesmen and domestic servants - according to Palárik, all lumberjacks and masons in Budapest were Slovaks. Men would often find work in the Buda brickyards, as navies and canal cleaners and reinforcing the banks of the Danube, while women found employment as domestic servants or laborers. For example, there were almost 400 Slovaks mostly of Orava extraction working in Jozef Zarzetzky's matchstick factory in Pest. Slovak historiography, especially in the work of Miroslav Huska, has devoted much attention to the Liptauer masons great numbers of whom took part in the construction of the new capital and who constituted a quite idiosyncratic group: for example, while most Slovak laborers would find work in Budapest either on their own or they would use the services of agents, Liptauer masons were highly organized. According to Huska's data, in 1856 there were about 2,000 masons working in Budapest, but by 1870, this figure more than doubled to 4,000-5,000. ${ }^{19}$ The Slovak community, however, centered on Slovak intelligentsia and bourgeoisie devoted to the national cause. After the fall of neo-absolutism, their ranks were joined by a great number of young Slovaks who came to Budapest for education, many of whom would then settle down in the city and become active members of the community.

The years between 1850 and the early 1870 were relatively favorable to the Slovak national cause and its proponents, but the situation changed rapidly once the Hungarian government shut down Matica slovenská and the Slovak secondary schools. This raises the question of what share of Slovak families in Pešt'budín decided to raise their children to be aware of their heritage and how many decided to raise them as Hungarians. A definitive answer to that question cannot be given, it is, however, certain that both scenarios were common. The Krekáč and the Zimáni families were the major Slovak families which took an active part in the social and cultural life of the Slovak community in Budapest. Daniel Krekáč who was actually born in Pest, studied at the secondary school in Revúca and joined the national movement as early as 1870s. His father Ján owned a number of houses and parcels of land in Pest and financially supported various Slovak institutions starting in the 1860s. ${ }^{20}$ Martin Bzdúch, who moved to Pest in the 1860 s to study medicine, ${ }^{21}$ also married in the Krekáč family. Another physician, Ján Dalibor Zimáni, was renowned for his contribution to the national cause in the 1840s-1860s and his son Ján took up his mantle in the 1880s and 1890s.

\section{Ibidem.}

18 PETRO, Ladislav: Ján Palárik v Pešti, in: Európan Ján Palárik, ZEMKO, Pavol (ed.), B. d. v. 2009, 69; VAVROVIČ, Jozef: Ján Palárik. Jeho ekumenizmus a panslavizmus, Martin 1993.

19 HUSKA, 72-79; PALÁRIK, Odpověd' na "Ozvěnu z Peště", 232.

20 KLEIN, 226.

21 Národné noviny, 1872, Year 2, No. 44, 13 April, 3. 
Jozef Pozdech, a prominent businessman of Slovak extraction, took great care to provide his children with an education which emphasized their Slovak heritage. Ján Nepomuk Bobula ${ }^{22}$ married his daughter Marína and their children also received homeschooling in Slovak, but they were enrolled in Hungarian schools. Their eldest son Ján, born in 1871, had Josip Strossmayer, the Croatian bishop of Djakov and an important figure of the Croatian national revival, as his godfather, which shows his father's dedication to the Slavic cause. But as Ján N. Bobula climbed the social ladder, his identification with the Slovak people and the Slovak national cause took a back seat to his ambitions, although he never went as far as outright opposition to it. In fact, as his correspondence with Andrej Kmet' and František Sláma shows, he maintained contact with major figures of the Slovak and the Slavic national movement. ${ }^{23}$ However, his son Ján, who went on to run his father's business, is known for his ardent opposition to the Slovak national cause and its representatives.

\section{The Federal Life of Slovaks}

The Budapest Slovak community reflected the general nature of the Slovak national movement at the time. Those Slovak intellectuals whose activities peaked in the 1820s and 1830s (Ján Kollár, Martin Hamuljak, Ján Herkel', Ján Koiš, Martin Sucháň etc.) are known for their close cooperation with the representatives of other Slavic nations in Peštbudín and their focus on the institutional backbone of the movement - periodicals, cultural societies and educational institutions. Their work culminated in the founding of the Slovak Language and Literature Society (Spolok milovníkov reči a literatúry slovenskej; 1834) and the almanac Zora (1835-1840). At the time, however, the national movement failed to resolve the primary issue of the national standard language. Consequently, Pešt'budín was the host to both the faction that favored the use of Czech (Ján Kollár and his followers) as well as those who adopted Bernolák's standard Slovak (Martin Hamuljak and the Slovak Language and Literature Society).

In the late 1840s, the influence of Ján Kollár and Martin Hamuljak ${ }^{24}$ waned and a new generation, the followers of Štúr and his new standard Slovak, took over the intellectual leadership of the Slovak community in Budapest. They were led by Ján Kadavý, ${ }^{25}$ a teacher at the Slovak Lutheran School, who in his Sunday school taught the entire generation of Slovak newcomers in Pest. It arrived in the city in the 1830s and the 1840s and then went on to assume positions of leadership within the Slovak Lutheran Assembly. The tension between Ján Kollár and Ján Kadavý escalated in 1847 when Kadavý resigned his post and left Pest. After the 1848/1849 revolution, the leadership of the national movement

22 Some of the latest work about J. N. Bobula: PETRO, Ladislav. Ján Nepomuk Bobula (1844-1903): Život a dielo, Budapest 2009; KAČíREK, Ĺuboš: Ján Nepomuk Bobula (1844 - 1903), in: Slováci v zahraničí, 30, Martin 2013, 34-53; SZISZÁKOVÁ, Sandra. Politické aktivity Jána Nepomuka Bobulu, Prešov 2014; DEMMEL, József: Magyar haza, szlovák nemzet. Alkotmányos szlovák politikai törekvések Magyarországon (1860-1872), Békéscsaba 2016, 76-113.

23 Letters of J. N. Bobulu. In: Zemský archiv v Opavě (Land Archive in Opava; hereinafter referred only as LA), fund František Sláma (1850-1917). Archív Muzeálnej slovenskej spoločnosti v Martine (Archive of Museum Slovak Society in Martin, hereinafter referred only as AMSS), fund Andrej Kmet..

24 More info: MAŤOVČíK, Augustín: Martin Hamuljak. (1789-1859). Život, dielo, osobnost', Bratislava 1971.

25 LUKÁČ, Michal: Ján Kadavý. Na 160. výročie narodenia, Martin 1970. 
in Peštbudín underwent a generational change: Ján Kollár resigned his post as the priest and the leader of the Slovak Lutheran assembly and left for Vienna. His replacement, Jozef Podhradský, was a significant supporter of the Štúr faction and by the 1850s, the Slovak Lutheran Assembly in Pest became an important center not only for Štúr's standard Slovak, but also for his political platform. On the other side of the confessional divide, the new generation of Slovak Catholic intelligentsia living in Budapest, which included Ján Palárik, Andrej Radlinský and Jozef Karol Viktorin, briefly returned to Czech and Bernolák's standard Slovak only to finally accept Štúr's standard Slovak after the Hodža-Hattala reform and Peštbudín thus became an important center in the spread of Štúr's standard Slovak. Budapest became home to the daily Katolícke noviny (Catholic News; 1849) which, in addition to Church matters, reported on current issues affecting the national movement and it was also where the Catholic students society was formed (1850-1874). In the 1850s, their activities focused on establishing a society for the advancement of the national cause referred to as Matica slovenská or "Národný dom" (National House, 1855-1857)26 and a Catholic Church society, Spolok sv. Vojtecha (St. Vojtech Society, 1857-1858).27 Although they ultimately failed, the funds they raised were instrumental in establishing both institutions in the 1860s. The social lives of the Slovak community in Budapest in the 1850s were limited to church functions and on Sundays and holidays, young people would often gather in pubs. The pub run by M. Fábry was one of such places, frequented especially by young apprentice craftsmen.

During the political thaw which followed the fall of neo-absolutism in the 1860s, another generational change took place in the leadership of the national movement in Budapest. The leaders of the 1850s like Ján Palárik, Andrej Radlinský and Jozef Podhradský slowly leave the city and their places are taken by Ján Francisci, Viliam Pauliny-Tóth and Adolf Dobriansky who found employment as government clerks and provide stamina for the national cause in Peštbudín. This period, 1859-1868, saw Peštbudín becoming the most important center of Slovak political and intellectual life. ${ }^{28}$ Pešt'budínske vedomosti (Pešt'budín Reporter; 1861 1870), the major journalistic outlet and the primary political organ of the new national movement, were published in Budapest and it was soon joined by a host of other Slovak publications (Černokňažník, Evanjelické církevní noviny, Junoš, Krajan, Priatel' ludu, Priatel' školy a literatúry). ${ }^{29}$ These years also saw more intense cooperation between the Slovak intellectual and political scene and their Czech, Serbian and Ruthenian counterparts. This period also marked an increased influx of Slovak seasonal laborers and especially Slovak students (Franko Kabina, Peter and Vojtech Matuška, Samuel Medvecký etc.) for whom the

26 Letter - Ján Palárik to Martin Hattala. Pešt' 9 February 1855. In: Památník národního písemnictví (Memorial of National Literature; hereinafter referred only as MNL), fund Martin Hattala.; Letter - Ján Palárik to Štefan Závodník. Pešt' 21 February 1857. In: Literární archiv, Slovenská národná knižnica (Archive of Literature, Slovak National Library; hereinafter referred only as AL SNL), signature M 116 B 47; List - Ján Palárik to Martin Hattala. Pešt' 29 October 1857. In: MNL, Fond Martin Hattala.

27 Prosba katolického Národu Slovenského na Jeho Eminenciu pána kardinála... za ....prijatie... Spolku sv. Vojtecha... In: Cyrill a Method, 1857, Year 8, 7 November, 145-148.

28 KISS, Csaba G.: Peštt a Budín ako duchovné strediská Slovákov, in: Kultúrne dedičstvo budapeštianskych Slovákov..., HRIVNAK, M. (ed.), 25-30.

29 BARNA, Ábrahám: Vydávanie slovenskej tlače a kníh v Budapešti v období dualizmu, in: Kultúrne dedičstvo budapeštianskych Slovákov..., HRIVNAK, M. (ed.), 57-69. 
magazine Junoš (Youth; 1865/1866) served as the official journalistic outlet. In the 1860s, even those members of Budapest bourgeoisie who were indifferent to the national cause until now, like Jozef Pozdech, joined the movement.

After the Austro-Hungarian Compromise of 1867, the capital of the Kingdom of Hungary again - after twenty years - saw the founding of a Slovak civic society: in January 1868, a young law student Matúš Dula led the initiative to establish a Slovenský spolok (Slovak Society, also known as Zábavno-poučný spolok; Pesti Tót Egylet) which includes university students and Pest bourgeoisie. At that time, however, a part of Slovak intelligentsia commonly known as the Old School - decided to leave Peštbudín. In 1870, the editorial board of Pešt'budínske vedomosti also left for Turčiansky Svätý Martin where it continued to publish the paper under the name Národné noviny. The Old School, renamed as the Slovak National Party in 1871,30 was determined to turn Turčiansky Svätý Martin into the primary political and cultural center for the new Slovak nation.

Those who remained in Budapest, known as the New School, ${ }^{31}$ advocated for cooperation with the Hungarian government to further their goals of increasing the participation of Slovaks in the administration of the country and improving the access to education by establishing more secondary schools with Slovak as the main language of instruction. Headed by Ján Nepomuk Bobula, the New School was headquartered in the Fabriková street in Theresa Town, organized around the magazine Slovenské noviny (1868-1875) and its members and sympathizers met under the auspices of the Národnodemokratický slovenský spolok (National Democratic Slovak Society, Pesti Nemzeti Demokrata Tót Kör, 1868-1869). The Theresa Town - which became the $\mathrm{V} \mathrm{I}^{\text {th }}$ district of the new capital which emerged from the amalgamation of Buda, Óbuda and Pest in 1872 - was home to the largest Slovak community in Budapest. This is where Jozef Pozdech had his home and his factory, this is where Ján N. Bobula lived, this is where the editorial offices of Slovenské noviny ${ }^{32}$ and the Minerva ${ }^{33}$ printing house were. The New School never managed to create a stable organizational structure, it was always more of a loose association of people around the Slovenské noviny magazine who supported its politics, shared its views and often even contributed to its pages. Attempts at turning this association into a political movement failed, but the activities of cultural associations and societies flourished. A large number of the supporters of the New School were drawn to its economic agenda and thus became supporters of the Minerva printing house and the credit cooperative in Pest.

The ranks of the rich Pest citizens who supported the New School were headed by Jozef Pozdech (1811-1878), Bobula's father-in-law and a proprietor of a bell factory, and Jozef

30 PODRIMAVSKÝ, Milan: Slovenská národná strana v druhej polovici XIX. storočia, Bratislava 1983.

31 KAČíREK, Ĺuboš: Prínos Novej školy (1868-1875) pre formovanie národného hnutia v 60. a 70. rokoch 19. storočia, in: Studia Academica Slovaca, 41, Bratislava 2012, 295-312; KOSTICKÝ, Bohuš: Nová škola slovenská: príspevok k problematike národnostnej otázky v Uhorsku v druhej polovici 19. storočia, Bratislava 1959; MARTINKOVIČ, Marcel: Politické myslenie Novej školy. Občiansko-národný program Slovenských novín, Bratislava 2013.

32 KAČíREK, Ĺuboš: Slovenské noviny (1868-1875), in: Studia Bibliographica Posoniensia, 2011, 55-72; ZAPLETAL, Vladislav: Vznik Bobulových Slovenských novín, in: Historický časopis, 3, 4, 1955, 489-529.

33 Podrobnejšie: KURUCOVÁ, Lívia: Minerva, prvá uhorsko-slovenská účastinná spoločnost', in: Studia Bibliographica Posoniensia 1/2007, 150-169; ZAPLETAL, Vladislav: Príspevok k dejinám Novej školy v rokoch 18691872 - Akciová tlačiareň Minerva, in: Historické štúdie, 2, 1956, 7-38. 
Zarzetzky (1805 - ca. 1885) who was originally from Poland and owned a matchstick factory. Older members of the Budapest bourgeoisie who were drawn to the New School included Ján Babilon (the author of the first cookbook in Slovak), Ján Brxa (manufacturer of pottery goods), Andrej Ivanovič (trader), Ján Kováč (trader and cobbler), Karol Križan, Ján Lenč, or Juraj Nigríni (carpenter). In the late 1860s and early 1870s, a generation of middle class tradesmen and businessmen who came to Budapest before the 1848/1849 revolution began to die out (e.g. J. Bohurád J. Krekáč).

The year 1871 saw a sharp uptick in the activities of Budapest Slovaks: earlier in the same year, Slovak university students established an academic society; in July, a credit cooperative was founded and in September, the Slovak Glee Society in Pest was formed. ${ }^{34}$ The New School attempted to guide the activities of these societies and mold them to be in line with its interests, however, none of them lasted. The Slovak Society was resurrected in 1873 as Zábavno-poučný slovenský spolok (The Slovak Society for Entertainment and Education) thanks to a number of students (Belo Klein-Tesnoskalský, Milan Lichard, Jozef Škultéty etc.) and the leadership of Daniel Bachát and the lawyer Jozef František Strakovič. The society was divided into three sections: the glee club, the educational club and the entertainment club. Its main purpose was to further the national cause among Slovak citizens of all social groups and as such, it published the magazine Dunaj, organized Slovak theatre performances and weekly dances which were very popular with tradesmen. In the 1870s, Slovak students would often meet in the Melferber brothers coffee house which was located close to the Luther Yard. It was also where the Slovak Society had its headquarters. As with all the citizens of Peštbudín, the Slovak community would often socialize in the context of seasonal dances and balls.

Peštbudín was a significant political and cultural center of the Slovak national movement for much of the long $19^{\text {th }}$ century, especially in the period between the 1820s and the early 1870s. This era, however, came to an end when the Hungarian authorities closed the Slovak secondary schools and Matica slovenská. In early 1875, the New School and their Slovenské noviny followed suit and the activities of the local Slovak community centered around the Slovak Lutheran assembly and the Slovak Society dropped sharply to recover only with the generational exchange of the early 1890s.

The Slovak community in Budapest continues to be active until this very day and has greatly influenced the image of Hungary's capital. Starting in late 1990s with the preceding volume Kultúrne dedičstvo budapeštianskych Slovákov (The Cultural Heritage of Budapest Slovaks; 1998), much effort has been expended to document the cultural heritage of Slovaks in Budapest. The Slovak self-government in Budapest has installed a number of plaques on buildings associated with important personalities in the Budapest Slovak community such as Ján N. Bobula's residence in the Andrássy Avenue (2003) or a plaque dedicated to the memory of Šimon Klempa (2007). ${ }^{35}$ In addition to the intangible cultural heritage, there are many tangible items connected with the history of the Budapest Slovak community, such as paintings by Ján Kollár and Pavol Jozef Šafárika currently housed at the Slovak Lutheran parish or the church flag of St. Cyril and Methodius in the St. Theresa Church.

34 KAČíREK, Národný život Slovákov ... ; KOVÁČOVÁ, Život a kultúra ...; KOVÁČOVÁ, Po stopách ...

35 KOVÁČOVÁ, Po stopách..., 295-297. 
Most tangible cultural heritage from the 1850 s to 1870 s is known to us second-hand only, through contemporary literature. Some of them were preserved in the Luther Yard parish, but no such items tied to the Budapest Slovak community from the years 1850-1879 are known to exist in Slovak museums, which highlights the need for further research into the cultural heritage of the community.

\section{References}

Archív Muzeálnej slovenskej spoločnosti v Martine (Archive of Museum Slovak Society in Martin), fund Andrej Kmet'.

Literární archiv, Slovenská národná knižnica (Archive of Literature, Slovak National Library), signature M 116 B 47.

Památník národního písemnictví (Memorial of National Literature), fund Martin Hattala. Zemský archiv v Opavě (Land Archive in Opava), fund František Sláma (1850-1917).

Cyrill a Method, Year $1-2,1850-1851$.

Cyrill a Method, Year $1-17,1852-1870$.

Katolícke noviny, Year $1-8,1849-1856$.

Národné noviny, Year $1-6,1870-1875$.

Pešt'budínske vedomosti, Year 1 - 10, 1861 - 1870.

Slovenské noviny, Year 1 - 13,1849-1861.

Slovenské noviny, Year 1 - 7, 1868 - 1874.

Slovenské pohlady, Year 39, 1923.

BARNA, Ábrahám: Vydávanie slovenskej tlače a kníh v Budapešti v období dualizmu, in: HRIVNÁK, M. (ed.): Kultúrne dedičstvo budapeštianskych Slovákov..., 57-69.

BELLA, Ján Pravdolub: Niektoré rozpomienky z rokov 1858-64, in: Slovenské pohlady, 38, $1922,9,520-523$.

BRTÁŇOVÁ, Erika - HUČKOVÁ, Dana - VANEKOVÁ, Ol'ga - MEZEIOVÁ, Adelaida: Listy Jána Kollára, in: XV. medzinárodný zjazd slavistov v Minsku. Príspevky slovenských slavistov, Bratislava 2013, 195-222.

Budapest statistics. Budapest 1945.

DEMMEL, József: Magyar haza, szlovák nemzet. Alkotmányos szlovák politikai törekvések Magyarországon (1860-1872), Békéscsaba 2016.

FABINY, Tibor: Kultúrny život slovenských evanjelikov v Pešt́budíne v 19. storočí, in: Kultúrne dedičstvo budapeštianskych Slovákov, HRIVNAK, M. (ed.), Budapest 1998, 31-34.

GAŠPARÍK, Mikuláš: Jozef Karol Viktorin (1822-1874). K 90. výročiu smrti, in: Slovenská literatúra, 10, 1963, 4, 405-418.

HALÁSZ, Ivan: Možnosti kariéry pre Slovákov počas dualizmu, in: Kultúrne dedičstvo budapeštianskych Slovákov, HRIVNAK, M. (ed.), Budapest 1998, 70-82.

HALÁSZ, Ivan: Cirkev, národ, štát. Daniel Bachát a jeho budapeštianske roky, Esztergom - Piliscsaba 2003.

HALÁSZ, Ivan: Ján Nepomuk Bobula, in: Szlovák életpályák a dualizmuskori Budapesten. Slovenské životné dráhy v Budapešti v období dualizmu, 57-67. 
HALÁSZ, Ivan: Vel'komesto a vel'komestské motívy v slovenskej literatúre 19. storočia. "Budapeštianski" autori slovenskej literatúry: Ján Palárik a Daniel Bachát, in: KOVÁČOVÁ, Identita, história a kultúra. Dejiny Slovákov na Dolnej zemi. (Zbornik konferencie 11.-12. novembra 2010), KOVAČOVA, Anna (ed.), Budapest - Bekešska Čaba 2011, 72-87.

HAPÁK, Pavol: Slovenské robotnícke hnutie v Budapešti koncom XIX. storočia, in: Historický časopis, 3, 1955, 1, 52-86.

HRIVNÁK, Michal (ed.): Kultúrne dedičstvo budapeštianskych Slovákov, Budapest 1998.

HUSKA, Miroslav: Liptovskí murári, Liptovský Mikuláš 1968.

JAROŠ, Peter: Tisícročná včela, Bratislava 1979.

KAČíREK, Ĺuboš: Slovenské noviny (1868 -1875), in: Studia Bibliographica Posoniensia, 2011, 55-72.

KAČíREK, L'uboš: Prínos Novej školy (1868-1875) pre formovanie národného hnutia v 60. a 70. rokoch 19. storočia, in: Studia Academica Slovaca, 41, Bratislava 2012, 295-312.

KAČíREK, Ĺuboš: Ján Nepomuk Bobula (1844-1903), in: Slováci v zahraničí, 30, Martin 2013, 34-53.

KAČíREK, Ĺuboš: Národný život Slovákov v Peštbudíne v rokoch 1850-1875, Békescsaba 2016.

KISS, Csaba G.: Pešt' a Budín ako duchovné strediská Slovákov, in: Kultúrne dedičstvo budapeštianskych Slovákov, HRIVNAK, M. (ed.), Budapest 1998, 25-30.

KISS SZEMÁN, Róbert: Slovanský Goethe v Pešti. Ján Kollár a národní emblematismus středoevropských Slovanů, Prague 2014.

KLEIN, Belo: Pred polstoletím. Rozpomienky na slovenskú koloniu v Pešt'budíne 1873, 1874, in: Slovenské pohlady, 39, 1923, 4 and 5, 220-231; 286-306.

KOSTICKÝ, Bohuš: Nová škola slovenská: príspevok k problematike národnostnej otázky $v$ Uhorsku v druhej polovici 19. storočia, Bratislava 1959.

KOVÁCS, Anna - MATUS, László: Jób megpróbáltatásai - egy evangélikus gyülekezet sorsfordulói. A pesti szlovák evangélikus gyülekezet emlékkönyve. Utrpenie Jóba peripetie jedného evanjelického zboru. Pamätnica peštianskeho slovenského evanjelického zboru, Budapest 2012.

KOVÁCS, Anna - SZABÓ, Orsolya (ed.): Szlovák életpályák a dualizmuskori Budapesten. Slovenské životné dráhy v Budapešti v období dualizmu. Ján Nepomuk Bobula. Milan Hodža, Budapest 2003.

KOVÁČOVÁ, Anna: Život a kultúra Slovákov v Budapešti v období dualizmu (1867 - 1918), Pilíšska Čaba - Ostrihom 2006.

KOVÁČOVÁ, Anna: Po stopách slovenskej minulosti Budapešti. Výber zo štúdií a prednášok, Budapest 2014.

KURUCOVÁ, Lívia: Minerva, prvá uhorsko-slovenská účastinná spoločnost', in: Studia Bibliographica Posoniensia 1/2007, 150-169.

LUKÁČ, Michal: Ján Kadavý. Na 160. výročie narodenia, Martin 1970.

MARTINKOVIČ, Marcel: Politické myslenie Novej školy. Občiansko-národný program Slovenských novín, Bratislava 2013.

MAŤOVČíK, Augustín: Martin Hamuljak. (1789-1859). Život, dielo, osobnost', Bratislava 1971. PETRO, Ladislav. Ján Nepomuk Bobula (1844-1903): Život a dielo, Budapest 2009.

PETRO, Ladislav: Ján Palárik v Pešti. In: Európan Ján Palárik, ZEMKO, Pavol (ed.), B. d. v. 2009, 67-74. 
PALÁRIK, Ján: Odpověd'na "Ozvěnu z Peště", in: Cyrill a Method, 9, 17 July 1858, 29, 231.

PODRIMAVSKÝ, Milan: Slovenská národná strana v druhej polovici XIX. storočia, Bratislava 1983.

RYBECKY, Milan: Prispevok k vyvinu muzealnej myšlienky na Slovensku v obdobi pat́desiatych rokov 19. storočia, in: Múzeum, 11, 1966, 3, 29-37.

SZISZÁKOVÁ, Sandra. Politické aktivity Jána Nepomuka Bobulu, Prešov 2014.

VAVROVIČ, Jozef: Ján Palárik. Jeho ekumenizmus a panslavizmus, Martin 1993.

VIRŠINSKÁ, Miriam: Evanjelická cirkev a. v. v Uhorsku a Slováci v druhej polovici 19. storočia, Martin 2011.

ZAPLETAL, Vladislav: Vznik Bobulových Slovenských novín, in: Historický časopis, 3, 4, 1955, 489-529.

ZAPLETAL, Vladislav: Príspevok k dejinám Novej školy v rokoch 1869-1872 - Akciová tlačiareň Minerva, in: Historické štúdie, 2, 1956, 7-38.

ZÁSZKALICZKY, Péter (ed.) Oltalom a zivatarban. Gyülekezet a világvárossá fejlődő Budapesten. Budapest 2011.

\section{Author}

Mgr. Ĺuboš Kačírek, PhD.

Katedra etnológie a muzeológie, Filozofická fakulta, Univerzita Komenského

Department of Ethnology and Museology, Faculty of Arts, Comenius University

Gondova 2, 81499 Bratislava 1, Slovakia

lubos.kacirek@gmail.com 